\title{
Theory of constraints: A state-of-art review
}

\author{
Maryam Orouji $\mathbf{i}^{\mathbf{a}, \mathbf{b}^{*}}$
}

${ }^{a}$ Department of Industrial Engineering, Iran University of Science and Technology, Tehran, Iran ${ }^{b}$ Nikan high School, Community Education Council District 2, Tehran, Iran

\section{H R O N I C L E \\ A B S T R A C T}

Article history:

Received June 5, 2015

Received in revised format

August 162015

Accepted December 152015

Available online

December 162015

Keywords:

Theory of constraints

Product mix

Cost accounting

\begin{abstract}
The theory of constraints (TOC) is a management tool, which considers any manageable system as being limited in reaching more of its objectives by some constraints. According to TOC, there is always, at least, one single constraint, and TOC implements a concentrating process to detect the constraint and restructure the remaining of the organization around it. This paper presents an overview of different perspectives of TOC and its implementation in different industries such as project management, quality management, outsourcing, product mix, maketo-buy, accounting, banking and health care, etc. The results indicate that the method has been extensively implemented in different areas of accounting.
\end{abstract}

C 2016 Growing Science Ltd. All rights reserved.

\section{Introduction}

The theory of constraints (TOC) is a management tool, which considers any manageable system as being limited in reaching more of its objectives by some constraints. According to TOC, there is always, at least, one single constraint, and TOC implements a concentrating process to detect the constraint and restructure the remaining of the organization around it. This paper presents an overview on different perspectives of TOC and its implementation in various industries such as product mix, scheduling, banking industry, etc.

\section{The Theory of Constraint}

Over the last two decades, several studies have been published on the contribution of the Theory of Constraints (TOC) and Throughput Accounting to product mix decisions (Fawcett \& Pearson, 1991; Blackstone, 2001; Cox III \& Schleier, 2010; Tulasi et al., 2012). The quality of the TOC-based method to build good or even optimal solutions can be evaluated with various results, specifically when compared with other product mix decision tools (Stein, 1997). Jones and Dugdale (1998) compared

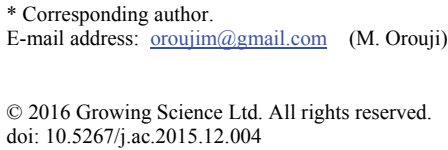


TOC with other management 'philosophies', and evaluated the treatment of measurement, behavior and objectives in enterprises. They also evaluated TOC's prospects of delivering the transformation in UK manufacturing which it promises. Souren et al. (2005) described that if more than one binding multi-product constraint happens, optimal product mix decisions can be extracted only in special cases.

According to Lee and Plenert (1993), TOC is a production control methodology, which maximizes profit in a factory by concentrating on bottlenecks. The process implemented by TOC determines the product mix in order to determine product mix. Activity-based costing (ABC) (Cooper \& Slagmulder, 1999; Schniederjans \& Garvin, 1997) and the TOC methods have created a significant literature, which reflects the relative importance of these topics. These two methods seem to represent conflicting viewpoints of product expense. Rather than attempting to resolve the question of who is right, each method is investigated in terms of its implicit assumptions about time horizons (Fritzsch, 2011). Nave (2002) explained different criteria for choosing TOC method compared with other methods such as Six Sigma and Lean thinking (Moore \& Scheinkopf, 1998). Table 1 presents the preliminary objectives of each method.

\section{Table 1}

The focus of various methods for improvement (Nave, 2002)

\begin{tabular}{llll}
\hline Program & \multicolumn{1}{c}{ Six Sigma (Ehie \& Sheu, 2005) } & Lean thinking (Bhimani, 2002) & Theory of constraints \\
\hline Theory & \multicolumn{1}{c}{ Reduce variation } & \multicolumn{1}{c}{ Remove waste } & Manage constraints \\
\hline & 1. Define & 1. Identify value & 1. Identify constraint \\
2. Measure & 2. Identify value stream & 2. Exploit constraint \\
gpplications & 3. Analyse & 3. Flow & 3. Subordinate progress \\
& 4. Improve & 4. Pull & 4. Evaluate constraint \\
\hline Focus & 5. Control & 5. Perfection & 5. Repeat cycle \\
\hline
\end{tabular}

According to Nave (2002), TOC concentrates on system improvement. A system can be described as a series of inter-dependent processes where the performance of the entire chain depends on the strength of the weakest link. In all manufacturing processes, TOC focuses on the process that reduces the speed of product through the system. TOC includes five steps:

1. Identify the constraint,

2. Exploit the constraint,

3. Subordinate other processes to the constraint,

4. Elevate the constraint,

5. Repeat the cycle.

Identify: The constraint is discovered through different methods. The volume of work in queue next of a process operation is a primary indicator. Another instance is where goods are processed in batches.

Exploit: When the constraint is determined, the process can be improved or supported to reach its entire capacity without major cost changes, which means the constraint is exploited. Subordinate. Once the constraining process is operating at its maximum capacity, the speeds of other processes are functions of the speed or capacity of the constraint. Some processes may influence individual productivity for the advantage of the entire system. Subordinate processes can be determined in advance of the constraint through the value stream.

Elevate: Once the output of the overall system is not desirable, more improvement is needed. The firm may require some more changes to the constraint, which could be involved in capital improvement, reorganization or other major costs of time or money. 
Repeat: Once the first constraint is split, another component of the system or process chain represents the new constraint and the cycle of improvement is repeated. The performance of the whole system is re-evaluated by looking for the new constraint process, exploiting the process, subordinating and making new assessment. By concentrating on constraints, this method generates positive impacts on the flow time of the production through the system. Reduction of waste in the constraint obviously increase throughput. When the constraint is upgraded, variation is changed, and quality is getting better. Constraint concentration does not need intimate knowledge of data analysis.

TOC methodology is based on different assumptions as follows,

- The firm places a value on the speed at which its product or service travels through the system.

- Current processes are necessary to generate the desired output.

- The product or service design is assumed to be stable. Value added employees do not require to have an in-depth knowledge of this improvement methodology. Recommendations made by the workers are not considered necessary for successful use of the TOC. Firms with hierarchical structure and centralized knowledge value this technique (Smith, 1999).

Activity-based costing (ABC) and the theory of constraints (TOC) are alternative paradigms for modeling an organization's production structure. Kee (1995) explained how different perspectives of the TOC could be integrated with ABC. The results gave some insight about the interaction between the expense, physical equipment, and capacity of production activities. The model helped to determine an optimal production mix based on simultaneous assessment of $\mathrm{ABC}$ data and physical attributes of the production process. The work also gave insight to determine a bottleneck activity that constrains the company's production opportunities and could possibly lead to excess resources in the company's other production activities. Patterson, M. C. (1992) explained how two different methods of activitybased costing (1995) and theory of constraints (TOC) (Goldratt, 1990; Dettmer, 1997; Rahman, 1998; Watson et al., 2007) may solve a product-mixed problem and described that the results of their analysis may be implemented in the field of manufacturing as well as management accounting.

TOC is a multi-faceted systems techniques developed to help people and organizations think about their issues, develop alternative solutions and implement them successfully. Mabin and Balderstone (2003) developed a literature-based research project investigating the results of TOC implementation reported in the literature, which covers over 80 successful TOC applications, based on available quantitative data. They explained that substantial improvements in both operational and financial performance could be possible as a result of TOC implementation. In spite of extensive studies, the detected no evidence of failures. While reports were primarily from manufacturing organizations, the results could be generalizable to other kinds of firms, specifically to their operational perspectives (Dettmer, 1995; Zimmerman \& Yahya-Zadeh, 2011). Wei et al. (2002) compared the advantages and disadvantages of traditional project management and TOC project management and offered an enhanced TOC method for scheduling the project under resource constraint.

Coman and Ronen (2000) offered an analysis of the outsourcing problem by formulating the outsourcing problem as a Linear-Programming (LP) problem and determined an analytical solution. They offered an example investigating three decision models: standard cost accounting, standard TOC and their own solution. Their proposed model helped managers determine which products to produce and which one has to be outsourced. Fredendall and Lea (1997) proposed a revised TOC product mix heuristic to determine the optimal product mix under conditions where the traditional TOC heuristic fails. Lockamy III and Spencer (1998) examined the application of a TOC-based performance measurement system in an operating environment. Aryanezhad and Komijan (2004) explained the inefficiency of the traditional TOC in dealing with the multiple bottleneck problem and discussed the disadvantages and provided an improved algorithm. 
Lea and Min (2003) investigated the effect of various management accounting systems, manufacturing control systems and time horizon on manufacturing performance in an enterprise resource planning integrated environment. These systems incorporated traditional costing (Louderback \& Patterson, 1996), ACB and TOC accounting. Through a series of simulation experiments, they reported that ABC could enhance higher short- and long-term profit, better customer service and lower work-in-process inventory than traditional costing. On the other hand, throughput accounting in situations where organizations maintained high overhead expenses and relatively low labour and material costs, while carrying ending inventories because of demand uncertainty. In their survey, traditional costing performed better than throughput accounting by exploiting the real-time information sharing abilities of an enterprise resource planning system. Just-In-Time (JIT) manufacturing outperformed TOC in terms of short- and long-term profitability, customer service, and work-in-process inventory.

Watson and Patti (2008) studied the effect of buffering under JIT and TOC to determine whether or not a difference in performance exists in systems encountered with unplanned machine downtime. Comparisons were accomplished based on results achieved from simulation of a five-station cell utilized in computer substrate manufacturing. They reported that the TOC technique, drum-bufferrope (DBR), could achieve relatively higher levels of performance as measured by total output and lead time while reducing inventory needs relative to the examined JIT technique, Kanban. They also recommended that DBR systems were more robust than JIT systems because they were able to keep higher levels of system performance across a different inventory levels.

Gupta and Boyd (2008) described that TOC could serve as a general theory in operations management. They first studied linkages between TOC and the core concepts/components of operations management $(\mathrm{OM})$ and demonstrated how OM concepts could be integrated with TOC based on some evidences from the published TOC literature. Spencer and Cox (1995) and Spencer (1994) discussed optimum production technology and the theory of constraints. Mabin et al. (2001) re-investigated traditional views on change management, more specifically the resistance to change, and to recommend alternative views and a practical method for better managing change. They described TOC, which views resistance as a necessary and positive force, and explained how it could be applied in a case study involving a bank merger. Bramorski et al. (1996) are also others who used TOC for banking management. Siha (1999) provided a classified model for implementing TOC to service organizations. Umble et al. (2006) presented an empirical investigation on implementing TOC in a traditional Japanese manufacturing environment.

Balakrishnan and Cheng (2005) provided a comprehensive insight on some methodology based on spreadsheet LP, which provides enhanced solutions in complex environments with multiple products and bottleneck situations based on the TOC concept. Kirche et al. (2005) presented a method for maximizing supply chain profits with effective order management. The method was an integration of ABC and TOC with mixed-integer modelling. Jones and Dugdale (2001) developed the concept of an accounting regime in order to explore the nature and power of accounting in totality and to determine its dimensions. Motwani et al. (1996) and Breen et al. (2002) used the concept of TOC in health care. Naor et al. (2013) examined whether or not TOC satisfy the virtues of a good theory. Wahlers and Cox (1994) investigated competitive factors and performance measurement by implementing TOC to meet customer requirements. Boyd and Gupta (2004) suggested different hypotheses, which might be empirically examined to build constraints management as a recognized theory in the field of operations management.

Ioannou and Papadoyiannis (2004) presented a TOC based method for effective enterprise resources planning (ERP) implementations. They described the reasoning behind long implementation times and organizational issues that tantalize the deployment of ERP systems. The study concentrated on two perspectives of most implementation projects that create the majority of technical and functional problems and constitute the projects' bottleneck. The study proposed the classification of functional 
necessities into business critical and legally necessary, and discussed the distribution of code development for system not fully supported processes among these two classes. They applied TOC and proposed a coherent methodology for handling bottlenecks and efficiently planning the code development effort. In addition, they derived trade-offs between successful and on-time ERP implementations with managerial enforcement of best practices fully functional within major ERP systems. Fenbert and Fleener (2002) implemented TOC multi-project management in a research organization. The idea of TOC has been extended to problems with uncertainty. Bhattacharya et al. (2008), for instance, developed TOC method when all parameters were involved with uncertainty. One of the issues involved in production planning is to decide which product has to be outsourced. Hilmola (2001) presented a simple method for outsourcing low value added products. Raimona Zadry and Mohd Yusof (2006) presented a survey on the implementation of total quality management and TOC implementation in Malaysian automotive suppliers.

\section{Conclusion}

This brief survey has indicated that TOC has been capable of improvement in many industries such as product mix, accounting, banking, etc. The idea of TOC is based on detecting a critical bottleneck and attempting to remove the bottleneck in an attempt to upgrade the system to a new level. The present survey has indicated that TOC has had good potential to help managers improve productivity of different organizations. Table 2 shows different implementation of TOC.

\section{Table 2}

TOC implementation in various research areas

\begin{tabular}{l}
\hline Reference \\
\\
$\begin{array}{l}\text { Fenbert \& Fleener, 2002; Wei et al., 2002 } \\
\text { Dettmer, 1995, 1997; Ehie \& Sheu, 2005; Moore \& Scheinkopf, 1998; }\end{array}$ \\
Nave, 2002; Raimona Zadry \& Mohd Yusof, 2006; Siha, 1999; Stein, \\
1997 \\
Coman \& Ronen, 2000; Hilmola 2001 \\
Aryanezhad \& Komijan, 2004; Bhattacharya et al., 2008; Fawcett \& \\
Pearson, 1991; Fredendall \& Lea 1997; Gupta et al., 2008; Lea \& Min, \\
2003; Patterson, 1992; Souren et al., 2005; Umble et al., 2006 \\
Balakrishnan \& Cheng, 2005 \\
Bhimani et al., 2002; Cooper \& Slagmulder, 1999; Fritzsch, 2011; \\
Kee, 1995; Kirche et al., 2005; Ioannou \& Papadoyiannis, 2004; Jones \\
\& Dugdale, 1998, 2001; Louderback \& Patterson, 1996; Schniederjans \\
\& Garvin, 1997; Spencer, 1994; Watson \& Patti, 2008; Zimmerman \& \\
Yahya-Zadeh, 2011
\end{tabular}

\section{Acknowledgement}

The authors would like to thank the anonymous referees for constructive comments on earlier version of this paper. 


\section{References}

Aryanezhad, M. B., \& Komijan, A. R. (2004). An improved algorithm for optimizing product mix under the theory of constraints. International Journal of Production Research, 42(20), 4221-4233.

Balakrishnan, J., \& Cheng, C. H. (2005). The theory of constraints and the make-or-buy decision: an update and review. Journal of Supply Chain Management, 41(1), 40-47.

Bhattacharya, A., Vasant, P., Sarkar, B., \& Mukherjee, S. K. (2008). A fully fuzzified, intelligent theory-of-constraints product-mix decision. International Journal of Production Research, 46(3), 789-815.

Bhimani, A., Datar, S. M., \& Foster, G. (2002). Management and cost accounting. Harlow: Financial Times/Prentice Hall.

Blackstone, J. H. (2001). Theory of constraints-a status report. International Journal of Production Research, 39(6), 1053-1080.

Boyd, L., \& Gupta, M. (2004). Constraints management: what is the theory?.International Journal of Operations \& Production Management, 24(4), 350-371.

Bramorski, T., Madan, M.S. \& Motwani, J. (1996). Application of the theory of constraints in banks. The Bankers Magazine, 180(1), 53-59.

Breen, A. M., Burton-Houle, T., \& Aron, D. C. (2002). Applying the theory of constraints in health care: Part 1-the philosophy. Quality Management in Healthcare, 10(3), 40-46.

Coman, A., \& Ronen, B. (2000). Production outsourcing: a linear programming model for the theoryof-constraints. International Journal of Production Research, 38(7), 1631-1639.

Cooper, R., \& Slagmulder, R. (1999). Integrating activity-based costing and the theory of constraints. Strategic Finance, 80(8), 20.

Cox III, J., \& Schleier, J. (2010). Theory of constraints handbook. McGraw Hill Professional.

Dettmer, H. W. (1995). Quality and the theory of constraints. Quality Progress, 28(4), 77.

Dettmer, H. W. (1997). Goldratt's theory of constraints: a systems approach to continuous improvement. ASQ Quality Press.

Ehie, I., \& Sheu, C. (2005). Integrating six sigma and theory of constraints for continuous improvement: a case study. Journal of Manufacturing Technology Management, 16(5), 542-553.

Fawcett, S.E. \& Pearson, J.N. (1991). Understanding and applying constraint management in today's manufacturing environments. Production and Inventory Management Journal, 32(3), 46-55.

Fenbert, J.A. \& Fleener, N.K. (2002). Implementing TOC multi-project management in a research organization. Frontiers of Project Management Research and Application: Proceedings of PMI Research Conference 2002; 2002 July 14-2002 July 17; AIPM, USA; PMI.

Fredendall, L. D., \& Lea, B. R. (1997). Improving the product mix heuristic in the theory of constraints. International Journal of Production Research,35(6), 1535-1544.

Fritzsch, R. B. (2011). Activity-based costing and the theory of constraints: Using time horizons to resolve two alternative concepts of product cost.Journal of Applied Business Research (JABR), 14(1), 83-90.

Goldratt, E. M. (1990). Theory of constraints. Croton-on-Hudson, NY: North River.

Gupta, M. C., \& Boyd, L. H. (2008). Theory of constraints: a theory for operations management. International Journal of Operations \& Production Management, 28(10), 991-1012.

Hilmola, O. P. (2001). Theory of constraints and outsourcing decisions.International Journal of Manufacturing Technology and Management, 3(6), 517-527.

Kee, R. (1995). Integrating activity-based costing with the theory of constraints to enhance productionrelated decision-making. Accounting Horizons, 9, 48-61.

Kirche, E. T., Kadipasaoglu, S. N., \& Khumawala*, B. M. (2005). Maximizing supply chain profits with effective order management: integration of activity-based costing and theory of constraints with mixed-integer modelling.International Journal of Production Research, 43(7), 1297-1311.

Ioannou, G., \& Papadoyiannis, C. (2004). Theory of constraints-based methodology for effective ERP implementations. International Journal of Production Research, 42(23), 4927-4954. 
Jones, T. C., \& Dugdale, D. (1998). Theory of constraints: transforming ideas?. The British Accounting Review, 30(1), 73-91.

Jones, T. C., \& Dugdale, D. (2001). The concept of an accounting regime.Critical Perspectives on Accounting, 12(1), 35-63.

Lea, B. R., \& Min, H. (2003). Selection of management accounting systems in Just-In-Time and Theory of Constraints-based manufacturing. International Journal of Production Research, 41(13), 28792910.

Lee, T. N., \& Plenert, G. (1993). Optimizing theory of constraints when new product alternatives exist. Production and Inventory Management Journal,34(3), 51.

Lockamy III, A., \& Spencer, M. S. (1998). Performance measurement in a theory of constraints environment. International Journal of Production Research, 36(8), 2045-2060.

Louderback, J. G., \& Patterson, J. W. (1996). Theory of constraints versus traditional management accounting. Accounting Education, 1(2), 189-196.

Mabin, V. J., Forgeson, S., \& Green, L. (2001). Harnessing resistance: using the theory of constraints to assist change management. Journal of European Industrial Training, 25(2/3/4), 168-191.

Mabin, V. J., \& Balderstone, S. J. (2003). The performance of the theory of constraints methodology: analysis and discussion of successful TOC applications. International Journal of Operations \& Production Management,23(6), 568-595.

Moore, R., \& Scheinkopf, L. (1998). Theory of constraints and lean manufacturing: friends or foes. Chesapeake Consulting Inc.

Motwani, J., Klein, D., \& Harowitz, R. (1996). The theory of constraints in services: part 2-examples from health care. Managing Service Quality: An International Journal, 6(2), 30-34.

Naor, M., Bernardes, E. S., \& Coman, A. (2013). Theory of constraints: is it a theory and a good one?. International Journal of Production Research,51(2), 542-554.

Nave, D. (2002). How to compare six sigma, lean and the theory of constraints. Quality Progress, 35(3), 73-80.

Noreen, E., Smith, D., \& Mackey, J. T. (1995). Theory of Constraints and Its Implications for Management Accounting: A Report on the Actual Implementation of The Theory of Constraints. North River Press, Incorporated.

Patterson, M. C. (1992). The product-mix decision: a comparison of theory of constraints and laborbased management accounting. Production and Inventory Management Journal, 33(3), 80.

Rahman, S. U. (1998). Theory of constraints: a review of the philosophy and its applications. International Journal of Operations \& Production Management, 18(4), 336-355.

Raimona Zadry, H., \& Mohd Yusof, S. R. (2006). Total quality management and theory of constraints implementation in Malaysian automotive suppliers: a survey result. Total Quality Management, 17(8), 999-1020.

Schniederjans, M. J., \& Garvin, T. (1997). Using the analytic hierarchy process and multi-objective programming for the selection of cost drivers in activity-based costing. European Journal of Operational Research, 100(1), 72-80.

Siha, S. (1999). A classified model for applying the theory of constraints to service organizations. Managing Service Quality: An International Journal,9(4), 255-264.

Smith, D. (1999). The measurement nightmare: how the theory of constraints can resolve conflicting strategies, policies, and measures. CRC Press.

Souren, R., Ahn, H., \& Schmitz, C. (2005). Optimal product mix decisions based on the theory of constraints? Exposing rarely emphasized premises of throughput accounting. International Journal of Production Research, 43(2), 361-374.

Spencer, M. S. (1994). Economic theory, cost accounting and theory of constraints: an examination of relationships and problems. The International Journal of Production Research, 32(2), 299-308.

Spencer, M. S., \& Cox, J. F. (1995). Optimum production technology (OPT) and the theory of constraints (TOC): analysis and genealogy. The International Journal of Production Research, 33(6), 1495-1504.

Stein, R. E. (1997). The Theory of Constraints: Applications in Quality Manufacturing. CRC Press. 
Tulasi, C. L., Rao, A. R., \& Tirupati, A. P. (2012). Review on theory of constraints. International Journal of Advances in Engineering \& Technology,3(1), 334-344.

Umble, M., Umble, E., \& Murakami, S. (2006). Implementing theory of constraints in a traditional Japanese manufacturing environment: The case of Hitachi Tool Engineering. International Journal of Production Research,44(10), 1863-1880.

Wahlers, J. L., \& Cox, J. F. (1994). Competitive factors and performance measurement: applying the theory of constraints to meet customer needs.International Journal of Production Economics, 37(2), 229-240.

Watson, K. J., Blackstone, J. H., \& Gardiner, S. C. (2007). The evolution of a management philosophy: The theory of constraints. Journal of Operations Management, 25(2), 387-402.

Watson, K. J., \& Patti, A. (2008). A comparison of JIT and TOC buffering philosophies on system performance with unplanned machine downtime.International Journal of Production Research, 46(7), 1869-1885.

Wei, C. C., Liu, P. H., \& Tsai, Y. C. (2002). Resource-constrained project management using enhanced theory of constraint. International Journal of Project Management, 20(7), 561-567.

Zimmerman, J. L., \& Yahya-Zadeh, M. (2011). Accounting for decision making and control. Issues in Accounting Education, 26(1), 258-259. 